University of Nebraska - Lincoln

DigitalCommons@University of Nebraska - Lincoln

\title{
Modified Milling Procedure for Separating Endosperm and Nonendosperm Portions of the Wheat Kernel for Protein and Lysine Analysis
}

\author{
Kenneth P. Vogel \\ University of Nebraska-Lincoln, kvogel1@unl.edu \\ P. J. Mattern \\ USDA-ARS \\ G. W. Lenser \\ USDA-ARS
}

Follow this and additional works at: https://digitalcommons.unl.edu/usdaarsfacpub

Vogel, Kenneth P.; Mattern, P. J.; and Lenser, G. W., "Modified Milling Procedure for Separating Endosperm and Nonendosperm Portions of the Wheat Kernel for Protein and Lysine Analysis" (1976). Publications from USDA-ARS / UNL Faculty. 1877.

https://digitalcommons.unl.edu/usdaarsfacpub/1877

This Article is brought to you for free and open access by the U.S. Department of Agriculture: Agricultural Research Service, Lincoln, Nebraska at DigitalCommons@University of Nebraska - Lincoln. It has been accepted for inclusion in Publications from USDA-ARS / UNL Faculty by an authorized administrator of DigitalCommons@University of Nebraska - Lincoln. 


\title{
Modified Milling Procedure for Separating Endosperm and Nonendosperm Portions of the Wheat Kernel for Protein and Lysine Analysis ${ }^{1}$
}

\author{
K. P. Vogel, P. J. Mattern, and G. W. Lenser ${ }^{2}$
}

\begin{abstract}
Conventional milling does not uniformly separate endospirm and nonendosperm components of wheats (Triticun aestivum L.). Uniform separation of bran and endosperm is required for protein and lysine analyses because of a protein gradient in wheat endosperm. A modified milling procedure for separating endosperm and nonenclosperm components of the wheat kernel was evaluated for its utility in processing small breeder lots of seed for protein and lysine analyses. After conventional milling and sifting, the endosperm adhering to the bran was renloved by washing with a 80:20 (vol/vol) ethanol:acetone solution, filtered from the washing solution, dried, and adiled to the mill flour to reconstitute the endosperm. Reconstituted endosperm weight was used to calculate percent endosperm. Reasonably complete and uniform separations of the endosperm and nonendosperm compoutents were obtained without any appreciable loss of components. Endosperm percentages of the wheats tested ranged from 72.8 to $85.5 \%$. Endosperm protein percentages ranged from 10.8 to $21.0 \%$. Bran protein percentages ranged from 13.1 to $25.1 \%$. Endosperm lysine (percent of protein) percentages ranged from 2.1 to $3.1 \%$. Bran lysine (percent protein) percentages ranged from 3.2 to $5.0 \%$.
\end{abstract}

Additional index words: Triticum aestivum L., Wheat quality, Wheat bran.

Tritition

HE purpose of this study was to evaluate the utility of a modified milling procedure for separation of endosperm and nonendosperm portions of the whea: (Triticum aestivum L.) kernel of small breeder lots of seed for protein and lysine analyses. For the purpose of this paper, the term endosperm refers to the starchy endosperm and the term bran refers to the nonstarchy endosperm components of the wheat kernel including the aleurone layer.

Bran and germ are higher in protein and lysine content than the endosperm. This has been established by protein and lysine analyses of the products of milling and by protein analyses of dissected samples $(3,4$, $9,13,14,15,22)$. Kernel component lysine values from hand-dissected samples are not available. The high protein and lysine content of mill bran is due to high protein and lysine content of the aleurone layer (20).

Whole grain samples are generally used for analysis of protein and lysine content in breeding and genetic

\footnotetext{
${ }^{1}$ Contribution of the Dep. of Agronomy, Univ. of NebraskaLincoln, and the ARS, USDA, Lincoln, Neb. Part of a dissertation submitted by the senior author to the Graduate College of the Univ. of Nebraska-Lincoln in partial fulfillment of the Ph.D. degree. The research was supported in part by funds from tie Agency for International Development, U. S. Dep. of State, Washington, DC Contract Nos. AID/csd-1208 and AID/ ta-c 1903. Published as Paper No. 4040, Journal Series, Nebraska Agric. Exp. Stn. Received 27 Sept. 1975.

${ }^{2}$ Research agronomist, ARS, USDA, formerly NDEA Title IV fellow, Univ. of Nebraska-Lincoln; professor (cereal quality), Univ. of Nebraska-Lincoln; and manager, Quality Assurance Feed Division, ConAgra, Omaha, Neb.
}

research on wheat especially in initial trials. Variability of protein and lysine content among wheats could result from some wheats having a greater proportion of bran in their seed than other wheats.

It is impossible to obtain a complete separation of the endosperm from the bran by milling due to the anatomical structure of the wheat kernel. It is also difficult to obtain a uniform separation of bran and endosperm when milling wheats varying in hardness, especially where small lots of seed are involved. Uniform separation of bran and endosperm is essential for endosperm protein and lysine analyses because there is a protein gradient in wheat endosperm. The outer portion of wheat endosperm has a much higher protein content than the interior of the kernel $(4,12$, 17). Since lysine is a component of protein, a lysine gradient within the wheat endosperm would also be expected. Variation in protein and lysine in flour milled from different wheats could result from differences in milling and not from differences amorig wheats in endosperm protein and lysine.

Various methods have been used to separate the structural parts of the wheat kernel for chemical analyses. They include manual dissection of the untreated kernel, dissection after the kernel has been soaked in water, removal of unwanted parts by insect feeding, and by a combination of mechanical and chemical treatments of whole kernels and mill products (9). For methods other than manual dissection, there is some unavoidable contamination of one structural part with another. For methods involving chemical reagents there is also some alteration in the chemical composition. It is possible to analyze more numerous and larger lots of seed with nondissection methods, thus reducing the sampling error.

\section{MATERIALS AND METHODS}

Wheat samples used in this study were grown in an irrigated uursery at Yuma, Ariz. during the 1972-73 growing season in $1.8 \mathrm{~m}$ single row plots spaced $51 \mathrm{~cm}$ apart. Six check cultivars and 636 wheats from the USDA World Wheat Collection were grown. An augmented, randomized, complete block design (5) was used with the six check cultivars replicated four times. Whole grain protein and lysine results from this nursery have been reported (21). One hundred and twenty-nine wheats that represented the range of grain protein and lysine values of the World Collection Wheats and the four replications of the check cultivars were sampled for use in this study. The 153 wheat samples included spring and winter wheats of various market classes.

Large field plots of 'Atlas 66,' 'Nap Hal,' 'Centurk,' and 'Bezostaya' were grown at Yuma in 1973 for nutrition studies. Large lots of these wheats were milled on the Kansas State Univ. pilot mill. Centurk and Bezostaya were milled at a $70 \%$ extraction rate. The soft wheats, Atlas 66 and Nap Hal, did not yield $70 \%$ while flour. The millfeeds, excluding the mill bran, of Nap Hal and Atlas 66 were pin milled. Flour from the pin milled samples was added to the inill flour in sufficient quantity to obtain $70 \%$ extraction flour samples for these wheats. Starchy endosperm wa.s 
separated from mill bran samples of these wheats by using the bran washing procedure.

Twenty-gram samples of wheat were tempered to $14.5 \%$ moisture 24 hours before milling. Tempered wheat samples were milled on a Brabender Quadumat Jr. experimental mill. ${ }^{3}$ The sifter on the mill was removed. Bran was sifted from the mill flour by sifting for $90 \mathrm{sec}$ on a mechanical shaker using a $U$. S. standard testing sieve No. 50 with 297 micron mesh openings. The mill flour and mill bran were weighed after sifting. Milling yield was calculated as follows: milling yield $=$ [mill flour $\mathrm{wt}$ ] (mill flour $w t+$ mil bran $w t] \times 100$.

The method of washing the bran with an alcohol:acetone solution to remove adhering starchy endosperm was developed by Gene W. Lenser. The term "bran flour" refers to the starchy endosperm removed from the bran by the washing procedure.

The washing solution was an 80:20 (vol/vol) absolute ethanol: acetone solution. All of the bran obtained from milling a $20 \mathrm{~g}$ sample of wheat was placed in a small Osterizer ${ }^{3}$ blender jar. Fifty milliliters of the washing solution was added and the mixture was stirred for $1 \mathrm{~min}$ at slow speed on an Osterizer blender. The endosperm adhering to the bran was washed off and was suspended in the washing solution. After stirring, the bran flour suspension was filtered through a 70GG silk screen (mesh opening $=236$ microns). Fifty milliliters of the washing solution was added to the bran in the blender jar and the process was repeated. After decanting the bran flour suspensions, the bran was washed out of the blender jar with the washing solution onto the 70GG screen.

The screen and washed bran were placed on a watch glass and dried in a $55 \mathrm{C}$ oven for 12 hours. Suspended bran flour particles were filtered with a Gilman ${ }^{3}$ type $E$ fiberglass filter from the washing solution using vacuum filtration and were then placed on a watch glass and dried for 12 hours in a $55 \mathrm{C}$ oven. After drying, the bran flour was removed from the filter and ground with mortar and pestle. Bran flour and mill flour samples were placed in a humidity controlled cabinet $(10)$ for 72 hours to bring all the samples to a uniform moisture level. Samples were then weighed and their moisture contents determined. Sample weights were calculated to a dry weight basis. Bran flour was added to the mill flour to reconstitute the endosperm. Samples were thoroughly blended by shaking. The bran samples were placed in a humidity controlled cabinet (10) for 72 hours, weighed and ground using a Udy Cyclone Sample Mill. ${ }^{3}$ Whole kernel samples also were ground using a Udy Mill.

Whole kernel, reconstituted endosperm, ground bran, bran flour, and $70 \%$ extraction flour samples were analyzed for protein and lysine content. All samples were brought to uniform moisture levels in a controlled humidity cabinet and were then weighed on a dry weight basis for protein and lysine analysis. Macro-Kjeldahl procedure AACC method 46-12 (1) was used to determine nitrogen content of the samples. Protein content for all samples was calculated as $\mathbf{N} \times 5.7$. Ion exchange chromatography was used to determine lysine content of the samples (11). Laboratory variability in the Univ. of Nebraska Wheat Quality Lab. for percent protein is \pm 0.2 of a percentage point and for lysine (percent of sample) is \pm 0.01 of a percentage point (11).

Endosperm percentages, sample recovery percentages, and other pertinent data were calculated using the equations listed below. Bran refers to washed bran samples and the abbreviation, dwt, indicates dry weight. Kernel component weights, and protein and lysine (percent of sample) percentages were used to calculate the amount $(\mathrm{g})$ of protein and lysine in the endosperm and bran.

1. Endosperm $(\mathrm{dwt})=$ mill flour $(\mathrm{dwt})+$ bran flour $(\mathrm{dwt})$

2. Sample recovery $\%=[($ endosperm $(\mathrm{dwt})+$ Bran $(\mathrm{dwt})) /$ grain $(\mathrm{dwt})] \times 100$

3. \% endosperm of sample $=[$ endosperm (dwt)/(endosperm $(\mathrm{dwt})+$ bran $(\mathrm{d} w \mathrm{t}))] \times 100$

4. Calculated grain protein $\%=[$ (endosperm protein $(\mathrm{g})+$ bran protein (g))/(endosperm (dwt) + bran dwt) $] \times 100$

5. Calculated grain lysine (\% of sample) $={ }^{-} \mathrm{I}$ (endosperm lysine $(\mathrm{g})+$ bran lysine $(\mathrm{g}))$ / (endosperm $(\mathrm{dwt})+\operatorname{bran}(\mathrm{dwt}))] \times$ 100

\footnotetext{
${ }^{s}$ Mention of firm or trade products does not imply that they are endorsed or recommended by the USDA or the U. S. Dep. of State over other firms or similar products not mentioned.
}

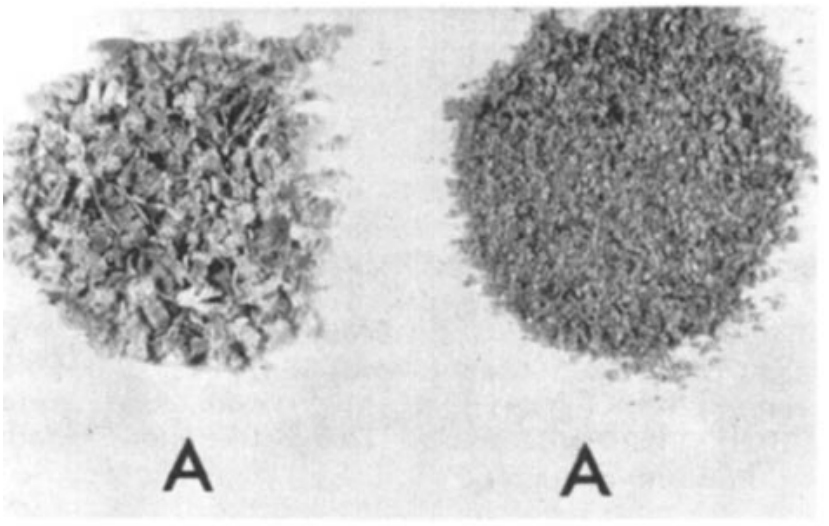

Fig. 1. Bran of the hard red winter wheat 'Scout 66' before (left) and after (right) washing with an 80:20 ethanol:acetone solution.

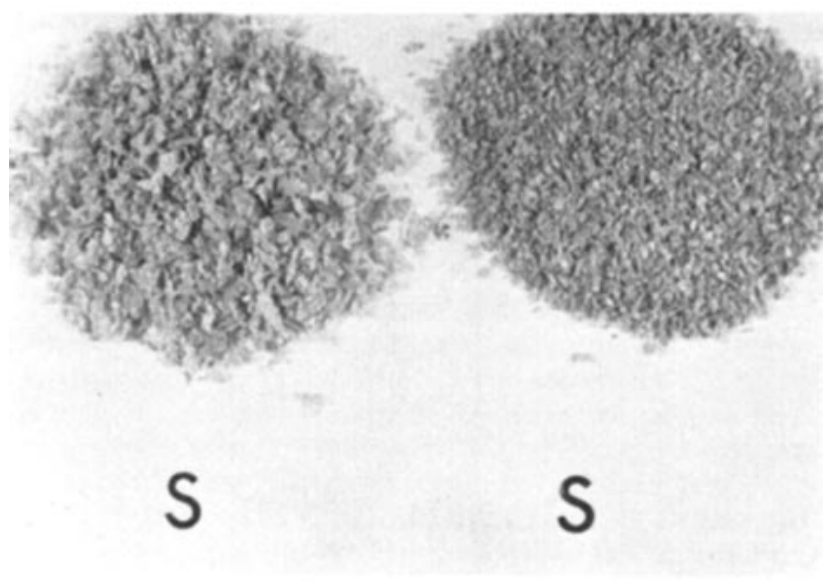

Fig. 2. Bran of the soft red winter wheat 'Atlas 66' before (left) and after (right) washing with an 80:20 ethanol:acetone solution.

6. \% of kernel protein in endosperm $=$ [endosperm protein $(\mathrm{g}) /$ (endosperm protein $(\mathrm{g})+$ bran protein $(\mathrm{g})$ ) $] \times 100$

7. \% of kernel lysine in endosperm $=$ [endosperm lysine (g)/ (endosperm lysine (g) + bran lysine $(\mathrm{g})] \times 100$

Bushel weight was measured using a 0.236 liter $(0.5$ pint) bucket with a standard drop. Bushel weight was converted to $\mathrm{kg} / \mathrm{hl}$ by multiplying by the factor 1.29 . Thousand-kernel samples were counted using an electronic seed counter.

\section{RESULTS AND DISCUSSION}

Miller's terminology is used in the results and discussion. The term endosperm refers to the starchy endosperm. Morphologically, the aleurone layer is also endosperm tissue. The bran samples obtained by milling on the Quadumat Jr. experimental mill contained both germ and bran. Except for the bran samples from the wheats milled on the Kansas State Univ. pilot mill, the terms "bran" or "washed bran" refer to the nonstarchy endosperm kernel components. On large mills such as the Kansas State Univ. pilot mill, the germ is sifted from the bran.

Figure 1 is a photograph of the bran of the hard red winter wheat, 'Scout 66,' before and after washing. Figure 2 is a photograph of the bran of the soft winter 
wheat Atlas 66. The bran samples were obtained by milling 20-g samples from check rows in the World Coliection Nursery. There is more of the white endosperm adhering to the mill bran of Atlas 66 than to the mill bran of Scout 66. After washing, there is no visible difference between the brans of the two wheats for endosperm content. Although the washed bran samples of both wheats still contain some endosperm, botll are cleaner and nore uniform than before washing. The endosperm content on a weight basis was $40.0 \%$ for Atlas 66 bran and $30.4 \%$ for Scout 66 bran.

Bran flour samples in this study did not contain visible bran contamination and resembled defatted flot:r in appearance and consistency. The aleurone layer of the washed bran samples was largely intact.

Means and ranges for milling yield, flour weight, bran flour weight, bran weight, and endosperm and sam.ple recovery percentages are listed in Table 1 . The amount of bran flour obtained from the mill bran of some of the soft wheats was large. The range for percent endosperm of sample is considerably smaller than the range in milling yield. The percent endosperm range values correspond to percent endosperm val des that have been reported by Hinton (6) Hinton et al. (7), MacMasters et al. (9), and Farrand and Hinton (4) for hand-dissected samples and are realistic considering the variability for hectoliter weight and kernel weight that exists among the wheats analyzed.

Means and the results of the analysis of variance of the check cultivars for kernel weight, milling yield, flo ar weight, bran flour weight, washed bran weight, sample recovery percent and percent endosperm are listed in Table 2. The check cultivars differed significantly for milling yield, flour weight, bran flour weight, washed bran weight, and percent endosperm. Alihough field replication had some effect on these

Table 1. Mean, range, and standard deviations for kernel components and kernel recovery percentages from the fractionation of 20.g samples for 153 samples from the 1973 World Wheat Collection nursery. $\dagger$

\begin{tabular}{|c|c|c|c|}
\hline Variables & Mean & Range & S.D. \\
\hline Fectoliter wt, $\mathrm{kg} / \mathrm{hl}$ & 77.89 & 70.95 to 83.85 & 2.279 \\
\hline 1,000 kernel wt, $g$ & 40.63 & 24.95 to 57.94 & 7.351 \\
\hline Nilling yield $\%$ & 71.2 & 63.1 to 78.8 & 3.18 \\
\hline Flour wt, gf & 12.70 & 11.28 to 14.09 & 0.58 \\
\hline Eran flour wt, g† & 1.60 & 0.92 to 2.50 & 0.390 \\
\hline Vlashed bran wt, gt & 3.15 & 2.56 to 4.77 & 0.309 \\
\hline$\%$ endosperm & 81.9 & 72.8 to 85.5 & 1.77 \\
\hline Sample recovery, \% & 98.1 & 96.3 to 99.2 & 0.50 \\
\hline
\end{tabular}

variables, most of the variation was due to differences among the wheats analyzed. Sample recovery percentage was not affected by cultivar or field replication. Considering the number of steps in the modified milling procedure, the sample recovery percentages are satisfactory.

The range in percent endosperm of sample was large. Part of the variation for percent endosperm can be attributed to within-nursery environmental variation since replications had a slight effect on percent endosperm. Most of the variation for percent endosperm was probably genetic in origin because there were highly significant differences among the check cultivars.

Soft wheats such as Atlas 66 and Nap Hal had lower endosperm percentages than the hard wheats Centurk and Scout 66. Part of the variation among the wheats for percent endosperm could be due to some wheats having thicker bran and aleurone layers than others $(2,8)$. Seed size could also be a factor.

There are large differences among the wheats for milling yield that are due almost entirely to kesnel texture. The mean milling yield of 'Triumph 64,' a hard red winter wheat, is 8.4 percentage points greater than that of Atlas 66. Triumph 64, however, is only 2 percentage points higher in endosperm percent. Atlas 66 had almost twice as much endosperm adhering to the bran as Triumph 64.

Whole grain protein and lysine percentages were calculated using endosperm and bran weights and protein and lysine percentages. The means, ranges, and standard deviations for measured and calculated protein and lysine (percent of sample) percentages are listed in Table 3. Calculated protein and lysine mean and range values are almost identical to the measured values. Little, if any, protein was lost in the washing process by solubilization of the bran and bran flour proteins in the 80:20 ethanol:acetone washing solution. These results are consistent with Osborne's (16) results for the solubility of wheat proteins. Gliadins are the only wheat proteins that are soluble in strong alcohol solutions (16). Their solubility increases with greater concentration of alcohol until a maxiraum solubility is reached at about $70 \%$ alcohol, then solubility decreases (16). It was evident that some lipids were dissolved in the washing solution because the bran flour had the consistency of defatted flour. Loss of these lipids had no apparent effect on the protein and lysine content of the endosperm or bran samples.

Wheats analyzed in this study represent a large range of kernel types and differ widely for kernel

Table 2. Means, coefficients of variation, $F$ ratios, and L.S.D. values for kernel components and kernel recovery percentages for check cultivars in the 1973 World Wheat Collection nursery. $†$

\begin{tabular}{|c|c|c|c|c|c|c|c|c|c|c|}
\hline \multirow[b]{2}{*}{ Variable } & \multicolumn{6}{|c|}{ Mean of check cultivars, $r=4$} & \multirow[b]{2}{*}{ c.V. } & \multirow{2}{*}{$\begin{array}{c}F \text { ratio for } \\
\text { cultivars }\end{array}$} & \multirow{2}{*}{$\begin{array}{c}\text { F ratio for } \\
\text { replications }\end{array}$} & \multirow{2}{*}{$\begin{array}{l}\text { L.S.D. } \\
\text { 1).05 }\end{array}$} \\
\hline & Atlas 66 & Triumph 64 & Scout 66 & Inia 66 & Centurk & Nap Hal & & & & \\
\hline & & & & & & & $\%$ & & & \\
\hline 1000-kernel wt. & 34.7 & 40.1 & 42.2 & 50.5 & 36.0 & 26.4 & 3.56 & $140.0 * *$ & $3.31 *$ & 2.06 \\
\hline Milling yield, \% & 65.8 & 74.2 & 76.3 & 75.9 & 74.5 & 68.8 & 0.57 & $419.06 * *$ & $4.47 *$ & 0.63 \\
\hline F'lour wt, g & 11.74 & 13.22 & 13.62 & 13.57 & 13.25 & 12.27 & 0.79 & $225.41 * *$ & $3.21 *$ & 0.15 \\
\hline Iiran flour wt, g & 2.26 & 1.19 & 1.18 & 1.08 & 1.30 & 1.86 & 4.69 & $185.43^{* *}$ & $11.20 * *$ & 0.10 \\
\hline Washed bran wt, $\mathrm{g}$ & 3.37 & 3.04 & 2.70 & 2.87 & 2.88 & 3.27 & 2.65 & $40.52 * *$ & $3.20 *$ & 0.12 \\
\hline ; endosperm & 80.59 & 82.56 & 84.56 & 83.63 & 83.44 & 81.23 & 0.55 & $44.42 * *$ & $3.17 *$ & 0.68 \\
\hline Eample recovery, \% & 97.67 & 98.11 & 98.43 & 98.50 & 98.02 & 97.82 & 0.54 & 1.53 & 1.31 & 0.80 \\
\hline
\end{tabular}

*:** Indicates significance at the 0.05 and 0.01 levels, respectively.

$\dagger$ Average dry $w \mathrm{t}$. of whole grain samples fractionated $=17.79 \mathrm{~g}$. 
weight, hectoliter weight, milling quality, and endosperm percent. The correlations for these traits are listed in Table 4. There was a highly negative correlation between milling yield and bran flour weight. As milling yield increased, the amount of endosperm remaining on the bran decreased. This high negative correlation provides evidence that the bran and endosperm of wheats differing in milling quality were uniformly separated by the bran washing process. Milling yield is highly correlated to percent endosperm. This is to be expected because the maximum yield of white flour from a sample of wheat is determined by the percent endosperm. The modified milling procedure may be useful to millers for estimating optimum milling yields. The correlations of hectoliter weight with both milling yield and percent endosperm were higher than those of 1000-kernel weight with milling yield and percent endosperm.

Mill flour samples from the wheats milled on the Kansas State Univ. pilot mill were lower in protein content than the whole grain or bran samples (Table 5). Mill bran samples were higher in both protein and lysine content than their whole grain samples. These results agree with those reported in the literature $(3,13,22)$. Lysine differences between grain and flour samples are of greater magnitude than the protein differences. Bran flour samples are much higher in protein content than the washed bran samples, but they are lower in lysine (percent of protein) content. Bran flour samples are considerably higher in both protein and lysine content than the $70 \%$ extraction flours.

The high protein content of the outer layers of the starchy endosperm has been reported previously (4, $12,17)$. The high protein of the bran flour samples provides further evidence that there is a strong protein gradient within a wheat kernel, even for wheats that are very high in protein.

Table 3. Means, ranges, and standard deviations for $\%$ protein and lysine (\% of sample) for grain samples obtained by whole kernel analysis and by calculation using endosperm and bran protein and lysine percentage for 153 samples from the 1973 World Wheat Collection nursery.

\begin{tabular}{lrrc}
\hline \multicolumn{1}{c}{ Variable } & Mean & Range & S.D. \\
& & & \\
Grain (\% protein) & 16.39 & 11.20 to 21.00 & 2.29 \\
Calculated grain (\% protein) $\dagger$ & 16.60 & 11.36 to 21.16 & 2.32 \\
Grain lysine (\% of sample) & 0.47 & 0.37 to 0.60 & 0.059 \\
Calculated grain lysine (\% of sample) $\dagger$ & 0.47 & 0.36 to 0.59 & 0.056 \\
\hline
\end{tabular}

$\dagger$ Correlation of calculated grain \% protein and grain $\%$ protein $=r=0.98$. ‡ Correlation of calculated grain lysine ( $\%$ of sample) and grain lysine ( $\%$ of sample $)=\mathbf{r}=0.93$

Table 4. Correlation coefficients for kernel traits for 153 samples from the 1973 world Wheat Collection nursery.

\begin{tabular}{llc}
\hline & Traits correlated & $\begin{array}{r}\text { Correlation } \\
\text { coefficient } \mathrm{r}\end{array}$ \\
\hline Hectoliter wt, $\mathrm{kg} / \mathrm{hl}$ & Milling yield & $0.41^{* *}$ \\
Hectoliter wt, kg/hl & \% endosperm of sample & $0.23^{* *}$ \\
1000 kernel wt, & Milling yield & $0.26^{* *}$ \\
1000 kernel wt, & \% endosperm of sample & $0.20^{*}$ \\
Milling yield & \% endosperm of sample & $0.70^{* *}$ \\
Milling yield & Bran flour wt, g & $-0.83^{* *}$ \\
Hectoliter wt, $\mathrm{kg} / \mathrm{hl}$ & 1000 kernel wt, g & $0.26^{* *}$ \\
\hline
\end{tabular}

*,** Indicates significance at the 0.05 and 0.01 levels, respectively.
The bran flour proteins are higher in lysine content than the $70 \%$ extraction flour proteins. This indicates that the endosperm proteins from the outer endosperm cells are higher in lysine than the endosperm proteins from the interior of the endosperm. However, the results of McDermott and Pace (12) indicate that the proteins of the outer endosperm cells are lower in lysine than the proteins of the inner endosperm.

McDermott and Pace (12) used a micro-drilling procedure to avoid contamination of endosperm samples with aleurone cells or cell contents. It is possible that the outer endosperm samples of McDermott and Pace (12) did not include the starchy endosperm cells adjacent to the aleurone layer.

Atlas 66 and Nap Hal have significantly higher protein content than Centurk or Bezostaya in both grain and $70 \%$ extraction flour (Table 5). The grain lysine (percent of protein) percentage of Nap Hal is higher than the grain lysine (percent of protein) values of the other wheats. Lysine (percent of protein) of Nap Hal $70 \%$ extraction flour is only slightly higher than the flour lysine (percent of protein) percentages of the other wheats.

These results illustrate the need for comparisons of whole grain, endosperm, and bran protein and lysine percentages to determine the within kernel site of protein and lysine variability among wheats. Because

Table 5. Whole grain, $70 \%$ extraction flour, bran, bran flour, and washed bran protein and lysine (\% of protein) percentages for four cultivars grown at Yuma, Ariz. in 1973.

\begin{tabular}{lcccc}
\hline & \multicolumn{4}{c}{ Cultivars } \\
\cline { 2 - 5 } \multicolumn{1}{c}{ Variables } & Atlas 66 & Centurk & Nap Hal & Bezostraya \\
\hline Whole grain \% protein & 17.2 & 15.0 & 18.5 & 13.2 \\
Whole grain lysine (\% of protein) & 2.86 & 2.90 & 3.05 & 2.80 \\
$\begin{array}{l}\text { 70\% extraction flour \% protein } \\
\text { 70\% extraction flour lysine }\end{array}$ & 17.2 & 12.4 & 16.5 & 11.1 \\
$\quad$ (\% of protein) & 2.12 & 2.18 & 2.20 & 1.99 \\
Bran flour \% protein & 26.6 & 26.4 & 28.3 & 23.2 \\
Bran flour \% lysine (\% of protein) & 3.31 & 4.22 & 3.12 & 4.12 \\
Bran \% protein & 19.3 & 18.9 & 23.9 & 16.10 \\
Bran lysine (\% of protein) & 4.00 & 4.46 & 4.04 & 4.57 \\
Washed bran \% protein & 18.0 & 17.8 & 23.3 & 14.2 \\
Washed bran lysine (\% of protein) & 4.38 & 4.67 & 4.71 & 4.85 \\
\hline
\end{tabular}

Table 6. Means, ranges, and standard deviations for percentage of whole kernel protein and lysine that is endosperm protein and lysine endosperm and bran protein and lysine percentages for 153 samples from the 1973 World Wheat Collection nursery.†t

\begin{tabular}{lccc}
\hline \multicolumn{1}{c}{ Variable } & Mean & Range & S.D. \\
\hline \% of kernel protein in endosperm $\dagger$ & 79.3 & 70.5 to 84.9 & 2.47 \\
\% of kernel lysine in endosperm $\neq$ & 68.0 & 58.8 to 74.8 & 2.94 \\
Endosperm \% protein & 16.1 & 10.8 to 21.0 & 2.43 \\
Endosperm lysine (\% of protein) & 2.45 & 2.14 to 3.08 & 0.166 \\
Bran \% protein & 19.0 & 13.1 to 25.1 & 2.40 \\
Bran lysine (\% of protein) & 4.40 & 3.23 to 4.97 & 0.286 \\
\hline
\end{tabular}

$\dagger \%$ of kernel protein in endosperm $=$ [endosperm protein (g)/total protein (g)] $\times 100$. $\$ \%$ of kernel lysine in endosperm $=$ [endosperm lysine (g) total lysine $(\mathrm{g})] \times \frac{+}{100}$. 
of the high protein and lysine content of the bran flour, it is necessary to obtain complete and uniformly separated samples of endosperm for protein and lysine analysis. Variation in milling yield could easily affect the protein and lysine content of endosperm samples. The: use of samples milled at a uniform extraction rate couid slightly distort endosperm protein and lysine relationships among wheats. Seventy percent extraction. flour from a wheat with $78 \%$ endosperm will contain more of the high protein outer endosperm than $70 \%$ extraction flour from a wheat with $85 \%$ endosperm.

$\mathrm{C}$ (n the average, $80 \%$ of the protein in wheat grain is endosperm protein, while only $68 \%$ of the total lysine resides in endosperm proteins. The means, ranges, and standard deviations for these variables are listed in Table 6 . The large range of values for percent of protein and lysine that is in the endosperm indicates that the distribution of protein and lysine within the wheat kernel varies significantly among wheats. The large range of values of endosperm and bran proteir. and lysine content indicates that there are differences among wheats for endosperm and bran protein and lysine content.

The results discussed previously demonstrate that the modified milling procedure can be used to obtain reasonably complete and uniform separation of the endosperm and nonendosperm components of the wheat kernel without appreciable loss of component or component proteins.

Over 15020 -g samples of wheat were separated into endosperm and nonendosperm components using the modified milling procedure. It would not have been possible to hand dissect this many samples in any reasonable period of time. Other mechanical and chemical methods have been used to separate and isolate kernel components for chemical analyses (18, 19, 20). In comparison with the other methods, the modified milling procedure is relatively simple and straightforward and can be used on all classes of wheat.

\section{LITERATURE CITED}

1. American Association of Cereal Chemists. 1962. AACC approved methods. Am. Assoc. Cereal Chem. Inc., St. Paul, Minn.

2. Bates, J. C. 1943. Varietal differences in anatomy of cross seclions of wheat grain. Bot. Gaz. 104:490-493.

3. Baumgarten, W., A. N. Mather, and L. Stone. 1946. Essential anino acid composition of feed material. Cereal Chem. 23:135-155.
4. Farrand, E. A., and J. J. C. Hinton. 1974. Study of relationships between wheat protein contents of two $U$. K. varieties and derived flour protein contents at varying extraction rates. II. Studies by hand dissection of individual grains. Cereal Chem. 51:66-74.

5. Federer, W. T. 1956. Augmented (or Hoonuiaku) designs. Hawaii. Plant. Rec. 40:191-207.

6. Hinton, J. J. C. 1959. The distribution of ash in the wheat kernel. Cereal Chem. 36:19-31.

7. - - F. C. Peers, and B. Shaw. 1953. The B vitamir in wheat: the unique aleurone layer. Nature 172:993-995.

8. Larkin, R. A., M. M. MacMasters, M. J. Wolf, and C. E. Fist. 1951. Studies on the relation of bran thickness to millability of some Pacific Northwest wheats. Cereal Chem. 28:247-:258.

9. MacMasters, M. M., J. J. C. Hinton, and D. Bradbury. 1971. Microscopic structure and composition of the wheat kernel. $p$. 51-113. In $\mathrm{Y}$. Pomeranz (ed.) Wheat chemistry and technology. Am. Assoc. Cereal Chem., Inc., St. Paul, Minn.

10. Mattern, P. J., and J. B. Bishop. 1973: A cabinet with controlled humidity to bring cereal samples to constant moisture. Cereal Sci. Today 18:8-10.

11. _-_, J. W. Schmidt, and V. A. Johnson. 1970. Screening for high lysine content in wheat. Cereal Sci. Today 15:409411.

12. McDermott, E. E., and J. Pace. 1960. Comparison of the amino acid composition of the protein in flour and endosperm from different types of wheat with particular reference to variation in lysine content. J. Sci. Food Agric. 11:109-115.

13. Millers' National Federation. 1967. Mill Feed Manual. Millers' Nat, Fed., Chicago, Ill.

14. Morris, V. H., T. L. Alexander, and E. D. Pascoe. 1945. Studies of the composition of the wheat kernel. II. Distribution of ash and protein in center sections. Cereal Chem. 22:35l-361.

15. - - - - - and - - -1946 . Studies of the composition of the wheat kernel. III. Distribution of ash and protein in central and peripheral zones of whole kernels. Cereal Chem. 23:540-547.

16. Osborne, T. B. 1907. The proteins of the wheat kennel. Carnegie Inst. Washington. Washington, DC.

17. Pomeranz, Y., and J. A. Shellenberger. 1961. Histochenical characterization of wheat and wheat products. II. Mapping of protein distribution in the kernel. Cereal Chem. 38:109113.

18. Shetlar, M. R., G. T. Rankin, J. F. Lyman, and W. G. France. 1947. Investigation of the proximate chemical composition of separate bran layers of wheat. Cereal Chem. 24:111-122.

19. Stenvert, N. L., and R. Moss. 1974. The separation and technological significance of the outer layers of the wheat grain. J. Sci. Food Agric. 25:629-635.

20. Stevens, D. J., E. E. McDermott, and J. Pace. 1963. Isolc.tion of endosperm protein and aleurone cell contents from wheat, and determination of their amino acid composition. J. Sci. Food Agric. 14:284-287.

21. Vogel, K. P., V. A. Johnson, and P. J. Mattern. 1975. Reevaluation of selected wheats from the USDA World Wheat Collection for protein and lysine content. Neb. Res. Bull. 272.

22. Waggle, D. H., M. A. Lambert, G. D. Miller, E. P. Farrell, and C. W. Deyoe. 1967. Extensive analysis of flours and mill feeds made from nine different wheat mixes. II. Amino acids, minerals, vitamins, ald gross energy. Cereal Chem. 44:48-60. 